\title{
Objawy mięśniowe w przebiegu stosowania statyn - fakty, mity, rzeczywistość i stanowiska ekspertów
}

\author{
Muscle symptoms on statins - facts, myths, reality, and expert statements
}

\author{
Katarzyna Starzyk ${ }^{1}$, Beata Wożakowska-Kapłon ${ }^{1,2}$ \\ ${ }^{1}$ I Klinika Kardiologii i Elektroterapii Świętokrzyskiego Centrum Kardiologii w Kielcach \\ ${ }^{2}$ Wydział Nauk o Zdrowiu Uniwersytetu Jana Kochanowskiego w Kielcach
}

\section{Streszczenie}

Statyny stanowią podstawę w leczeniu hipercholesterolemii. Wystąpienie dolegliwości mięśniowych związanych ze stosowaniem statyn (SAMS) jest jednym z głównych powodów zaprzestania stosowania leku i pozostawienia ryzyka wystąpienia incydentu sercowo-naczyniowego na nieobniżonym poziomie. Strategia optymalnego postępowania u pacjentów z SAMS powinna obejmować zastosowanie najlepiej tolerowanej przez chorego statyny, dawkowanej nawet rzadziej niż raz dziennie, lub zastosowanie leczenia skojarzonego z innym lekiem istotnie wpływającym na obniżenie cholesterolu frakcji LDL i o udowodnionym wpływie na zmniejszenie występowania zdarzeń sercowo-naczyniowych. Właściwe diagnozowanie objawów mięśniowych związanych i niezwiązanych ze stosowaniem statyn w przebiegu terapii tymi lekami oraz wdrożenie adekwatnego postępowania pozwala uzyskać korzyści wynikające z redukcji stężenia cholesterolu, z uniknięciem działań niepożądanych, i obniżenie ryzyka sercowo-naczyniowego.

Słowa kluczowe: statyny, hipercholesterolemia, objawy mięśniowe

(Folia Cardiologica 2015; 10, 5: 354-360)

\section{Wstęp}

Statyny stanowią podstawę w leczeniu hipercholesterolemii i równocześnie są najczęściej sprzedawanymi lekami. Ich przydatność w zapobieganiu ostrym stanom wynikającym z miażdżycy tętnic, takim jak zawał serca czy udar mózgu, opisano szczegółowo w wielu publikacjach i wytycznych postępowania. Wydłużanie średniej długości życia w naszej populacji osiągnięto również dzięki zmniejszeniu śmiertelności z powodu choroby wieńcowej. Tym niemniej nadal niewystarczające pozostaje modyfikowanie jednego z głównych czynników ryzyka miażdżycy, jakim jest hipercholesterolemia (podwyższone stężenie cholesterolu frakcji LDL [low-density lipoprotein]). W II Deklaracji Sopockiej, opublikowanej jesienią 2014 roku, wymieniono przyczyny słabej kontroli dyslipidemii w Polsce: nihilizm terapeutyczny (zmniejszanie dawek leków, gdy zostanie osiągnięta docelowa wartość cholesterolu w kontrolnym lipidogramie), wprowadzające w błąd normy dla zdrowej populacji podawane na wynikach testów laboratoryjnych - nieuwzględniające osób obciążonych wysokim i bardzo wysokim ryzykiem sercowo-naczyniowym, a przede wszystkim lęk przed pojawieniem się działań niepożądanych [1]. W 2015 roku ukazały się dwa bardzo interesujące dokumenty, których autorzy poddali szczegółowej analizie problem działań niepożądanych związanych ze stosowaniem statyn: stanowisko Panelu Ekspertów European Atherosclerosis Society (EAS) - „Ocena, etiologia i postepowanie w związanych ze stosowaniem statyn objawach mięśniowych" oraz stanowisko International Lipid Expert Panel - „Nietolerancja statyn, próba ujednolicenia definicji" [2, 3]. 


\section{Definicja objawów związanych ze stosowaniem statyn}

W badaniach obserwacyjnych z ostatnich 10 lat opisano wiele działań potencjalnie związanych ze stosowaniem statyn, takich jak: dolegliwości mięśniowo-kostne, dolegliwości żołądkowo-jelitowe, zmęczenie, podwyższenie aktywności aminotransferaz, neuropatia obwodowa, bezsenność, upośledzenie funkcji poznawczych. zaburzenia neurokognitywne. W badaniach randomizowanych zauważono niewielki wzrost ryzyka wystąpienia cukrzycy [4]. Wystąpienie dolegliwości mięśniowych związanych ze stosowaniem statyn (SAMS, statin-associated muscle symptoms) jest jednym z głównych powodów zaprzestania stosowania leku przez chorych i pozostawienia ryzyka wystąpienia incydentu sercowo-naczyniowego na nieobniżonym poziomie. Ważnym parametrem, związanym z oceną uszkodzenia mięśni, jest aktywność kinazy keratynowej (CK, creatine kinase) - enzymu wydostającego się z uszkodzonych komórek mięśniowych. Znaczne podwyższenie jej stężenia, tj. ponad 10 razy powyżej górnej granicy normy (ULN, upper limit of normal), podczas terapii statyną to sytuacja bardzo rzadka, bo w przypadku stosowania dużych dawek statyn występująca u 1 na 1000-1 na 10000 osób rocznie. W odróżnieniu od badań randomizowanych, w których częstość występowania dolegliwości pozostawała na poziomie placebo, rejestry pacjentów i doświadczenie kliniczne wskazują, że 7-29\% pacjentów zgłasza objawy mięśniowe w przebiegu stosowania statyn, którym towarzyszy prawidłowa lub nieznacznie podwyższona aktywność CK. Wystąpienie tych objawów prowadzi do przerywania terapii u istotnego odsetka pacjentów (nawet do 75\% w pierwszych 2 latach). W metaanalizie badań randomizowanych wykazano o 15\% niższe ryzyko incydentów wśród chorych stosujących statyny zgodnie z zaleceniami w porównaniu z pacjentami niepodejmującymi terapii [5]. Istotne jest, by pacjenci zgłaszający objawy mięśniowe otrzymywali optymalne leczenie obniżające stężenie cholesterolu frakcji LDL i redukujące ryzyko sercowo-naczyniowe.

Jedynym, jak podają eksperci, dotychczas badaniem randomizowanym, przeprowadzonym metodą podwójnie ślepej próby, poświęconym wpływowi statyn na wystąpienie i rozwój dolegliwości mięśniowych, było: The Effects of Statins on Muscle Performance (STOMP) [6]. Czterysta dwadzieścia, dotąd nieleczonych, osób losowo przydzielono do grup - leczonej 80 mg atorwastatyny lub przyjmującej placebo; terapię kontynuowano przez 6 miesięcy. Objawy spełniające kryterium mialgii zgłosiło 9,4\% osób przyjmujących statynę i 4,6\% pacjentów z grupy otrzymującej placebo $(p=0,054) \cdot W$ badaniu STOMP nie stwierdzono też istotnej różnicy między grupami w pomiarach siły mięśniowej lub wydolności wysiłkowej. Jednak nawet nieznaczny odsetek występowania mialgii wciąż oznacza istotną liczbę pacjentów, biorąc pod uwagę znaczną liczbę osób leczonych statynami. Zhang i wsp. [7] wykazali, że 90\% pacjentów zgłaszających SAMS podczas leczenia jedną statyną tolerowało inną (w obserwacji 12-miesięcznej), co sugeruje, że objawy te mogą mieć inne przyczyny i nie można ich odnosić w jednakowym stopniu do wszystkich leków z tej grupy. Analizowano również przyczyny patofizjologiczne, które mogą odpowiadać za ich występowanie, i wskazano: pogorszenie funkcji mitochondriów, spowolnienie produkcji związków energetycznych, zmianę trybu degradacji białek sarkomeru [2].

Aby stwierdzić, że objawy mięśniowe rzeczywiście są spowodowane działaniem statyny, należy przeprowadzić rzetelny proces diagnostyczny. Eksperci zalecają, by podstawami rozpoznania SAMS były charakter dolegliwości mięśniowych, ocena aktywności CK oraz związek czasowy z początkiem, przerwaniem i ponownym wprowadzeniem leczenia statyną.

W pierwszej kolejności należy uściślić charakter objawów, wśród których mogą występować przede wszystkim ból lub tkliwość mięśni. Inny charakter objawów mięśniowych to sztywność, osłabienie lub kurcze. Ból i osłabienie siły mięśni w typowym SAMS są zwykle symetryczne i proksymalne; w większości przypadków odnoszą się do dużych grup mięśni, na przykład ud, pośladków, goleni, grzbietu. Rzadziej występują jako zlokalizowane i może im towarzyszyć osłabienie siły mięśniowej. Dyskomfort lub osłabienie typowo pojawiają się w ciągu 4-6 tygodni od rozpoczęcia leczenia, ale mogą również wystąpić dopiero po wielu latach terapii. Wystąpienie objawów może być spowodowane zwiększeniem dawki statyny lub włączeniem leku pozostającego z nią w interakcji. Objawy bywają bardziej nasilone u osób aktywnych fizycznie. Objawy mięśniowe występujące w przebiegu stosowania statyn mogą być bardziej lub też mniej nasilone przy ponownej ekspozycji na określoną statynę.

Podczas leczenia statynami bardzo rzadko występuje zwiększenie aktywności CK, wobec czego nie zaleca się jej rutynowego monitorowania. Nawet jeśli stwierdzi się podwyższenie stężenia u pacjenta bez objawów, to znaczenie kliniczne tego faktu, w odniesieniu do stosowanego leku, jest wątpliwe (tab. 1).

\section{Czynniki ryzyka wystąpienia objawów mięśniowych podczas leczenia statyną}

Wzrost aktywności CK zależy od rodzaju stosowanej statyny i narasta nie tylko wraz ze zwiększeniem dawki, ale także w przypadku obecności czynników związanych ze wzrostem stężenia statyny w surowicy krwi - genetycznych, etnicznych, interakcji z innymi lekami, indywidualnych cech pacjentów. Niebezpiecznym działaniem niepożądanym jest rabdomioliza - ciężka postać uszkodzenia mięśni ze znacznym podwyższeniem wartości CK oraz mioglobinemią i/lub mioglobinurią, a w konsekwencji zwiększonym ryzykiem 
Tabela 1. Definicja objawów mięśniowych związanych ze stosowaniem statyn (wg Panelu Ekspertów EAS [2])

\begin{tabular}{|c|c|c|}
\hline Objawy & Biomarker & Komentarz \\
\hline Objawy mięśniowe & $\mathrm{CK} w / \mathrm{n}$ & $\begin{array}{l}\text { Często określane jako „mialgia”. Mogą się wiązać ze stosowaniem statyn, tym niemniej } \\
\text { ta zależność jest niepewna z powodu braku zróżnicowania nasilenia objawów u pacjen- } \\
\text { tów przyjmujących badany lek v. placebo w badaniach randomizowanych przeprowadzo- } \\
\text { nych metodą podwójnie ślepej próby }\end{array}$ \\
\hline Objawy mięśniowe & $\mathrm{CK}>\mathrm{ULN}<4 \times \mathrm{ULN}$ & $\begin{array}{l}\text { Niewielki wzrost aktywności CK, zwykle związany ze zwiększeniem aktywność fizycznej } \\
\text { lub znacznym wysiłkiem, może się również wiązać ze stosowaniem statyny, wskazując na } \\
\text { zwiększone ryzyko występowania poważniejszej, dotąd nierozpoznanej, choroby mięśni }\end{array}$ \\
\hline Objawy mięśniowe & CK > $10 \times$ ULN & $\begin{array}{l}\text { Często określane jako miositis lub „miopatia” przez organy nadzorujące badania rando- } \\
\text { mizowane (nawet w przypadku braku biopsji mięśni lub klinicznie istotnego osłabienia } \\
\text { mięśni), w których częstość występowania oszacowano na 1/10 000/rok. Typowo ból } \\
\text { jest uogólniony, proksymalny; mogą mu towarzyszyć tkliwość i osłabienie; może się wią- } \\
\text { zać z chorobą mięśni }\end{array}$ \\
\hline Objawy mięśniowe & $\mathrm{CK}>40 \times \mathrm{ULN}$ & $\begin{array}{l}\text { Określane jako „rabdomioliza”, jeśli towarzyszą pogorszenie funkcji nerek i/lub mioglo- } \\
\text { binuria }\end{array}$ \\
\hline Brak & $\mathrm{CK}>\mathrm{ULN}<4 \times \mathrm{ULN}$ & $\begin{array}{l}\text { Diagnozowane przypadkowo podwyższenie aktywności CK może się wiązać ze stosowa- } \\
\text { niem statyny; związane z wysiłkiem fizycznym. Rozważyć kontrolę funkcji tarczycy }\end{array}$ \\
\hline Brak & $\mathrm{CK}>4 \times \mathrm{ULN}$ & $\begin{array}{l}\text { Niewielkie podwyższenie aktywności CK u pacjentów bez objawów obserwowano w ba- } \\
\text { daniach randomizowanych, w których rutynowo je oznaczano - wymaga kontroli, tym } \\
\text { niemniej jego istotność kliniczna przy utrzymywaniu się zwiększonych wartości jest } \\
\text { niepewna }\end{array}$ \\
\hline
\end{tabular}

EAS - European Atherosclerosis Society; CK (creatine kinase) - kinaza kreatyny; ULN (upper limit of normal) - górna granica normy

niewydolności nerek. Występuje ona jednak bardzo rzadko, z częstością około 1 na 100000 przypadków rocznie. Jeśli pacjent zgłasza objawy mięśniowe, to należy określić czynniki ryzyka predysponujące do miopatii i wykluczyć jej inne przyczyny, na przykład niedoczynność tarczycy, inne miopatie, takie jak polimialgia reumatyczna czy zwiększona aktywność fizyczna. Konieczne jest ścisłe przestrzeganie wskazań do leczenia statyną. Należy pamiętać, że inne, często przepisywane leki, zarówno takie jak przeciwzapalne (steroidy), antypsychotyczne (risperidon, haloperidol), immunosupresyjne lub przeciwwirusowe (inhibitory proteazy ludzkiego wirusa niedoboru odporności [HIV, human immunodeficiency virus]), jak i inne substancje (np.: alkohol, opioidy, kokaina) mogą zaburzać funkcję mięśni. Określone czynniki, takie jak: płeć żeńska, grupa etniczna, choroby układowe, drobna budowa ciała, predysponuja do wystąpienia SAMS (tab. 2) [2]. Prawdopodobieństwo wystąpienia objawów zwiększa się wprost proporcjonalnie do liczby tych czynników.

Jednoczesne leczenie statyną i lekami wpływającymi na izoenzymy cytochromu P450 (CYP450), aniony organiczne białek transportowych 1B1 (OATP 1B1, organic anion transporting protein 1B1) i glikoproteinę P 1 (P-gp) zwiększa ryzyko wystąienia nowych objawów lub nasilenia obecnych już dolegliwości mięśniowych. Istnieje możliwość wystąpienia objawów w związku z interakcją działania leków, tj. w przypadku jednoczesnego stosowania: gemfibrozilu, makrolidów, azolowych pochodnych leków przeciwgrzybiczych, inhibitorów proteaz, leków immunosupresyjnych, na przykład cyklosporyny, Należy pamiętać, że politerapia - zarówno lekami przepisywanymi, jak i dostępnymi bez recepty (np. witaminy, minerały, preparaty ziołowe) - jest potencjalnym tłem wystąpienia interakcji.

\section{Postępowanie w przypadku wystąpienia objawów mięśniowych w trakcie terapii statyną}

Podstawowym krokiem diagnostycznym jest udowodnienie, że objawy rzeczywiście występują po zastosowaniu statyny i ustępują wraz z zaprzestaniem leczenia, a pojawiają się po ponownym podaniu leków. Aby ustalić związek przyczynowy, trzeba odstawić lek na pewien czas, a następnie ponownie go wprowadzić (tab. 3).

Gdy obecność przyczyn wtórnych oraz czynników predysponujących zostanie wyjaśniona, to należy uaktualnić obecność wskazań do stosowania statyn. W przypadku osób cechujących się niskim ryzykiem sercowo-naczyniowym należy razem z pacjentem podjąć indywidualną decyzję odnośnie proponowanej terapii i odpowiednio wybrać - jeśli dyskomfort może być tolerowany, to stosować statynę, a jeśli nie, to odstawić lek i zintensyfikować zmiany stylu życia, co obejmuje: zaprzestanie palenia papierosów przez pacjenta, zoptymalizowanie leczenia hipotensyjnego, zaadoptowanie do możliwości chorego zasady diety śródziemnomorskiej. Natomiast u osób obciążonych wysokim ryzykiem sercowo-naczyniowym należy dążyć do utrzymania leczenia. Jeśli objawy/podwyższenie stężenia fosfokinazy kreatynowej 
Tabela 2. Czynniki ryzyka wystąpienia związanych ze statynami objawów mięśniowych (adaptowane wg [2])

\begin{tabular}{|c|c|}
\hline \multirow[t]{4}{*}{ Antropometryczne } & $\begin{array}{l}\text { Wiek > } 80 \text { lat (zalecana czujność } \\
>75 \text { lat) }\end{array}$ \\
\hline & Płeć żeńska \\
\hline & Niski BMI \\
\hline & Rasa azjatycka \\
\hline \multirow{9}{*}{$\begin{array}{l}\text { Schorzenia } \\
\text { współistniejące }\end{array}$} & Ostra infekcja \\
\hline & $\begin{array}{l}\text { Niedoczynność tarczycy (leczona } \\
\text { lub nie) }\end{array}$ \\
\hline & $\begin{array}{l}\text { Uszkodzenie nerek ( } \geq 3 \text {. stadium } \\
\text { niewydolności) lub wątroby }\end{array}$ \\
\hline & Niedrożność dróg żółciowych \\
\hline & Stan po transplantacji narządów \\
\hline & Ciężkie urazy \\
\hline & Zakażenie HIV \\
\hline & Cukrzyca \\
\hline & Niedobór witaminy D \\
\hline Leczenie chirurgiczne & $\begin{array}{l}\text { Zabiegi ze zwiększonym zapotrze- } \\
\text { bowaniem metabolicznym (AHA } \\
\text { zaleca czasowe odstawienie statyny } \\
\text { przed dużym zabiegiem) }\end{array}$ \\
\hline \multirow[t]{3}{*}{ Inne schorzenia } & $\begin{array}{l}\text { Wywiad podwyższenia CK, zwłasz- } \\
\text { cza > } 10 \times>\text { ULN }\end{array}$ \\
\hline & $\begin{array}{l}\text { Wywiad uprzednich/niewyjaśnio- } \\
\text { nych dolegliwości mięśni/ścięgien/ } \\
\text { /stawów }\end{array}$ \\
\hline & $\begin{array}{l}\text { Zapalne lub dziedziczno-metabo- } \\
\text { liczne, nerwowo-mięśniowe/ } \\
\text { /mięśniowe schorzenia (np. gliko- } \\
\text { genoza - choroba McArdle’a, } \\
\text { deficyt palmitoilotransferazy karni- } \\
\text { tynowej typu II, deficyt deaminazy } \\
\text { adenylanowej mięśni [AMPD-1], } \\
\text { hipertermia złośliwa) }\end{array}$ \\
\hline Genetyczne & $\begin{array}{l}\text { Czynniki genetyczne, takie jak } \\
\text { polimorfizm genów kodujących } \\
\text { izoenzymy cytochromu P450 } \\
\text { lub transporterów leków }\end{array}$ \\
\hline \multirow[t]{4}{*}{ Inne } & Wysoki poziom aktywności fizycznej \\
\hline & $\begin{array}{l}\text { Czynniki dietetyczne (nadmierne } \\
\text { spożycie soku grejpfrutowego } \\
\text { lub żurawinowego) }\end{array}$ \\
\hline & Nadmierne spożycie alkoholu \\
\hline & $\begin{array}{l}\text { Używki (kokaina, amfetamina, } \\
\text { heroina) }\end{array}$ \\
\hline
\end{tabular}

BMI (body mass index) - wskaźnik masy ciała; HIV (human immunodeficiency virus) - ludzki wirus niedoboru odporności; AHA - American Heart Association; CK (creatine kinase) - kinaza kreatynowa; ULN (upper limit of normal) - górna granica normy; AMPD-1 - adenosinemonophosphate deaminase 1
Tabela 3. Postępowanie podczas wystąpienia objawów mięśniowych

Upewnić się, że są wskazania do stosowania statyn i pacjent
ma świadomość korzyści wynikających z takiego leczenia
Upewnić się, że nie ma przeciwwskazań do stosowania statyn
Udzielić wsparcia pacjentowi obawiającemu się możliwych
działań niepożądanych, informując, że istnieją skuteczne
sposoby ich ograniczania
Podkreślić znaczenie czynników dietetycznych i związanych
ze stylem życia
Jeśli przerwanie i wznowienie terapii nie ogranicza objawów
mięśniowych, to zastosować mniejszą dawkę lub dawkowanie
z przerwami, preferując inną (skuteczną) statynę
Zastosować leczenie skojarzone statyną i innym lekiem
o udokumentowanym wpływie na obniżenie ryzyka sercowo-
-naczyniowego (ezetimib)
Zastosować terapię uzupełniająca, aby osiągnąć cel terapii
(docelowe stężenie cholesterolu frakcji LDL)
Choć brakuje dowodów z badań randomizowanych potwier-
dzających skuteczność łagodzenia objawów mięśniowych, to
w indywidualnych przypadkach można rozważyć zastosowanie
koenzymu Q10
LDL - low-density lipoprotein

(CPK, creatine phosphokinase) ustąpią po odstawieniu leku, to należy rozważyć zastosowanie mniejszej dawki tego samego leku, innej statyny albo leczenia skojarzonego z ezetimibem (Ezetrol ${ }^{\circledR}$, MSD). W przypadku dobrej tolerancji można zwiększać dawkę leku tak, aby osiągnąć cel terapii lub jak największą redukcję wartości cholesterolu frakcji LDL. Jeżeli proponowana strategia nie będzie skuteczna, to alternatywą pozostaje stosowanie leku co 2. dzień lub 2 razy w tygodniu - tak aby osiągnąć docelowe stężenie cholesterolu frakcji LDL. W badaniach klinicznych, mimo ograniczeń metodologicznych (mała liczebność, ocena retrospektywna, metoda badania otwartego [bez ślepej próby], brak randomizacji), udowodniono, że stosowanie leku co 2. dzień/2 razy w tygodniu powoduje obniżenie stężenia cholesterolu frakcji LDL u 12-38\% pacjentów i jest dobrze tolerowane u około $70 \%$ pacjentów z występującymi wcześniej objawami mięśniowymi. Podsumowując, najbardziej właściwe jest zastosowanie mniejszej dawki mocnej statyny o długim okresie półtrwania (atorwastatyny, rosuwastatyny i niedostępnej jeszcze w Polsce pitawastatyny).

Jeśli nie osiągnięto docelowego stężenia cholesterolu frakcji LDL u pacjenta z grupy wysokiego ryzyka sercowo-naczyniowego, to - mimo stosowania maksymalnej, ale tolerowanej dawki statyny - należy rozważyć inne metody leczenia, aby go uzyskać. Skutecznym lekiem, przy niewielkim nasileniu objawów mięśniowych, jest ezetimib, który dołączony do terapii statyną zapewnia dodatkową redukcję stężenia cholesterolu frakcji LDL o 15-20\% 
oraz zapewnia udokumentowany w randomizowanym, kontrolowanym badaniu klinicznym (IMPROVE-IT, IMProved Reduction of Outcomes: Vytorin Efficacy International Trial) wpływ na obniżenie ryzyka sercowo-naczyniowego [8]. Obecnie obowiązujące standardy postępowania obligują lekarzy do uzyskiwania u chorych obciążonych bardzo wysokim ryzykiem sercowo-naczyniowego, a więc u tych, którzy są objęci wskazaniem refundacyjnym dla leku Ezetrol ${ }^{\circledR}$ (ezetimib), obniżenia cholesterolu frakcji LDL poniżej wartości $70 \mathrm{mg} / \mathrm{dl}$. Biorąc pod uwagę standardy postępowania terapeutycznego Polskiego Towarzystwa Kardiologicznego (ESC, European Society of Cardiology) oraz dążenie do celów terapeutycznych, należy wskazać na konieczność przewlekłej kontynuacji rozpoczętej terapii skojarzonej statyną z lekiem Ezetrol ${ }^{\circledR}$, która jest dostępna dla pacjentów w ramach refundacji. By doprecyzować tę kwestię, warto w tym miejscu przypomnieć stanowisko Departamentu Polityki Lekowej i Farmacji Ministerstwa Zdrowia przekazane w odpowiedzi na zapytanie z 3 lipca 2015 roku, wskazujące zasady refundacji tego leku: „Zgodnie z obwieszczeniem ministra zdrowia z dnia 24 czerwca 2015 r. w sprawie wykazu refundowanych leków, środków spożywczych specjalnego przeznaczenia żywieniowego oraz wyrobów medycznych (Dz. Urz. Min. Zdrow. 2015.27) lek Ezetrol ${ }^{\circledR}$ jest refundowany w następującym zakresie wskazań objętych refundacją: hipercholesterolemia (stężenie cholesterolu frakcji LDL > $130 \mathrm{mg} / \mathrm{dl}$ ) utrzymująca się mimo terapii statynami w przypadku: stanu po zawale serca lub rewaskularyzacji wieńcowej (przezskórnej lub kardiochirurgicznej), stanu po rewaskularyzacji obwodowej lub amputacji obwodowej z powodu choroby miażdżycowej, hipercholesterolemii rodzinnej. Powyższe kryterium jest fundamentem w podejmowaniu decyzji o możliwości finansowania ze środków publicznych wybranego dla pacjenta w ww. stanie klinicznym, właściwego procesu terapeutycznego. Należy je traktować jako kryterium wyjściowe do rozpoczęcia terapii. Obniżoną odpłatność można również stosować w okresie prowadzonej terapii, ponieważ jest to kontynuacja rozpoczętego procesu terapeutycznego".

Zastosowanie ezetimibu w połączeniu ze statyną (fluwastatyna XL) u pacjentów z objawami mięśniowymi pozwoliło na obniżenie wartości cholesterolu frakcji LDL o 46\% [9].

Cholestyramina, kolesewelam oraz kolestipol zmniejszają wartość cholesterolu frakcji LDL o 15-25\%, w zależności od leku i stosowanej dawki, obniżając również glikemię u chorego na cukrzycę. Kolesewelam jest łatwiejszy do stosowania i lepiej tolerowany niż cholestyramina i kolestipol, jednak zastosowanie tych leków jest ograniczone niewygodnym stosowaniem (forma podania, działania niepożądane), a w Polsce dodatkowo koniecznością sprowadzania w ramach importu docelowego oraz wysoką ceną. Przyjmowanie tych leków łącznie z ezetimibem może obniżyć stężenie cholesterolu frakcji LDL o 30-35\%.
W armamentarium leków hipolipemizujących jest również fenofibrat, który obniża stężenie cholesterolu frakcji LDL 0 15-20\%, również u pacjentów bez hipertriglicerydemii. Jest łatwy do stosowania, a jego bezpieczeństwo w leczeniu udowodniono w badaniu ACCORD (Action to Control Cardiovascular Risk in Diabetes and Fenofibrate Intervention and Event Lowering in Diabetes Trials) [10]. W przeciwieństwie do gemfibrozilu dodanie fenofibratu do statyny nie zwiększało ryzyka wystąpienia rabdomiolizy [10].

W 2014 roku w Unii Europejskiej wycofano z użycia kwas nikotynowy, obniżający stężenie cholesterolu frakcji LDL o 15-20\%. W randomizowanych badaniach udowodniono, że podczas jego stosowania łącznie ze statyną zwiększała się częstość występowania ciężkich działań niepożądanych przy braku korzyści sercowo-naczyniowych [11].

Spożywanie pokarmów wzbogaconych o sterole lub stanole (2 g/d.) albo rozpuszczalny błonnik (np. psyllium, tj. łupiny nasion babki jajowatej; $10 \mathrm{~g} / \mathrm{d}$.), będących dodatkiem do diety z niską zawartością tłuszczów nasyconych i ograniczeniem kwasów tłuszczowych trans, można obniżyć stężenie cholesterolu frakcji LDL, odpowiednio, o 10\% i 7\%. Dieta Portfolio, zawierająca sterole roślinne, białko soi, rozpuszczalny błonnik i orzechy, potencjalnie obniża stężenie cholesterolu frakcji LDL o 2-25\%.

Choć nie ma dowodów z badań randomizowanych wskazujących na skuteczne łagodzenie objawów mięśniowych związanych ze stosowaniem statyn przez suplementy diety, takie jak ubichinon (koenzym Q10) czy preparaty witaminy $\mathrm{D}$, to w poszczególnych przypadkach można rozważyć ich zastosowanie.

Preparaty z czerwonego ryżu poddanego fermentacji grzybem Monascus purpureus obniżają stężenie cholesterolu frakcji LDL o 20-30\% w krótkoterminowych badaniach randomizowanych. Te efekty działania wiążą się z obecnością monakoliny $\mathrm{K}$ - substancji o działaniu porównywalnym z lowastatyną ograniczającą syntezę cholesterolu przez hepatocyty, jak również ze sterolami roślinnymi zmniejszającymi jego absorbcję jelitową. Jakkolwiek badania z ostatnich lat wskazują, że preparaty sfermentowanego czerwonego ryżu są dobrze tolerowane, to pozostaje wiele niewyjaśnionych zagadnień, takich jak na przykład dowody odnośnie korzyści z wieloletniego stosowania, brak wystandaryzowanej biodostępności różnych preparatów czy potencjalna toksyczność związana z obecnością zanieczyszczeń. Co więcej, preparaty sfermentowanego czerwonego ryżu mogą wywoływać objawy mięśniowe, w związku z działaniem analogicznym do statyn. Dlatego zastosowanie monakoliny u pacjentów obciążonych wysokim ryzykiem sercowo-naczyniowym wymaga uzyskania pozytywnych wyników w randomizowanych, wieloośrodkowych badaniach.

Nowością są preparaty inhibitorów konwertazy białkowej subtilizyny keksyny typu 9 (PCSK9, proprotein convertase subtilisin/kexin type 9), które mogą być alternatywą 
dla pacjentów z objawami mięśniowymi. Jest to białko osoczowe łączące się z receptorami LDL na powierzchni błon komórkowych hepatocytów, co następnie prowadzi do jego degradacji. Cząsteczka PCSK9 została zidentyfikowana w 2003 roku i powiązana z hipercholesterolemią dziedziczoną autosomalnie dominująco. Stała się celem terapeutycznym nowych metod obniżania cholesterolu frakcji LDL u ludzi. Intensywnym badaniom poddano ludzkie przeciwciała monoklonalne - ewolokumab, alirokumab i bokocyzumab. Wykazano w ich przypadku znaczne obniżenie stężenia cholesterolu frakcji LDL, aż o 50-60\% w różnych grupach pacjentów, obejmujących także osoby źle tolerujące statyny. Badaniom poddano ponad 6000 pacjentów leczonych przez 3-12 miesięcy, udowadniając dobrą tolerancję podskórnie podawanych preparatów, z rzadkim występowaniem odczynów skórnych i brakiem wzrostu parametrów wątrobowych lub CPK [2]. Na ich podstawie 21 lipca 2015 roku Europejska Agencja Leków (EMA, European Medicines Agency) wydała pozytywną opinię w sprawie dopuszczenia do obrotu ewolokumabu (Repatha ${ }^{\circledR}$, Amgen), zalecając stosowanie tego leku u dorosłych pacjentów z pierwotną hipercholesterolemią (heterozygotyczną hipercholesterolemią rodzinną i nierodzinną) oraz z dyslipidemią mieszaną, jako uzupełnienie diety. Kolejny przedstawiciel tej grupy, alirokumab (Praluent $^{\circledR}$, Sanofi-Regeneron), został zatwierdzony do obrotu przez amerykańską Agencję ds. Żywności i Leków (FDA, Food And Drug Administation) 24 lipca 2014 roku oraz uzyskał pozytywną opinię Komitetu ds. Produktów Leczniczych Stosowanych u Ludzi (CHMP, Committee for Medicinal Products for Human Use) przy EMA. We wrześniu 2015 roku alirokumab (Praluent ${ }^{\circledR}$ ) został też dopuszczony do stosowania na terenie Unii Europejskiej przez Komisję Europejską. Zapowiedziano, że wstępne wyniki kolejnych czterech badań służących analizie wpływu stosowanego leczenia na ryzyko sercowo-naczyniowe zostaną opublikowane w 2017 roku.

Kolejnymi cząsteczkami, pozostającymi w fazie badań, są inhibitory białka transferującego estry cholesterolu (CETP, cholesterol-ester transfer protein). Transferazy białkowe uczestniczą w przenoszeniu estrów cholesterolu i triglice-

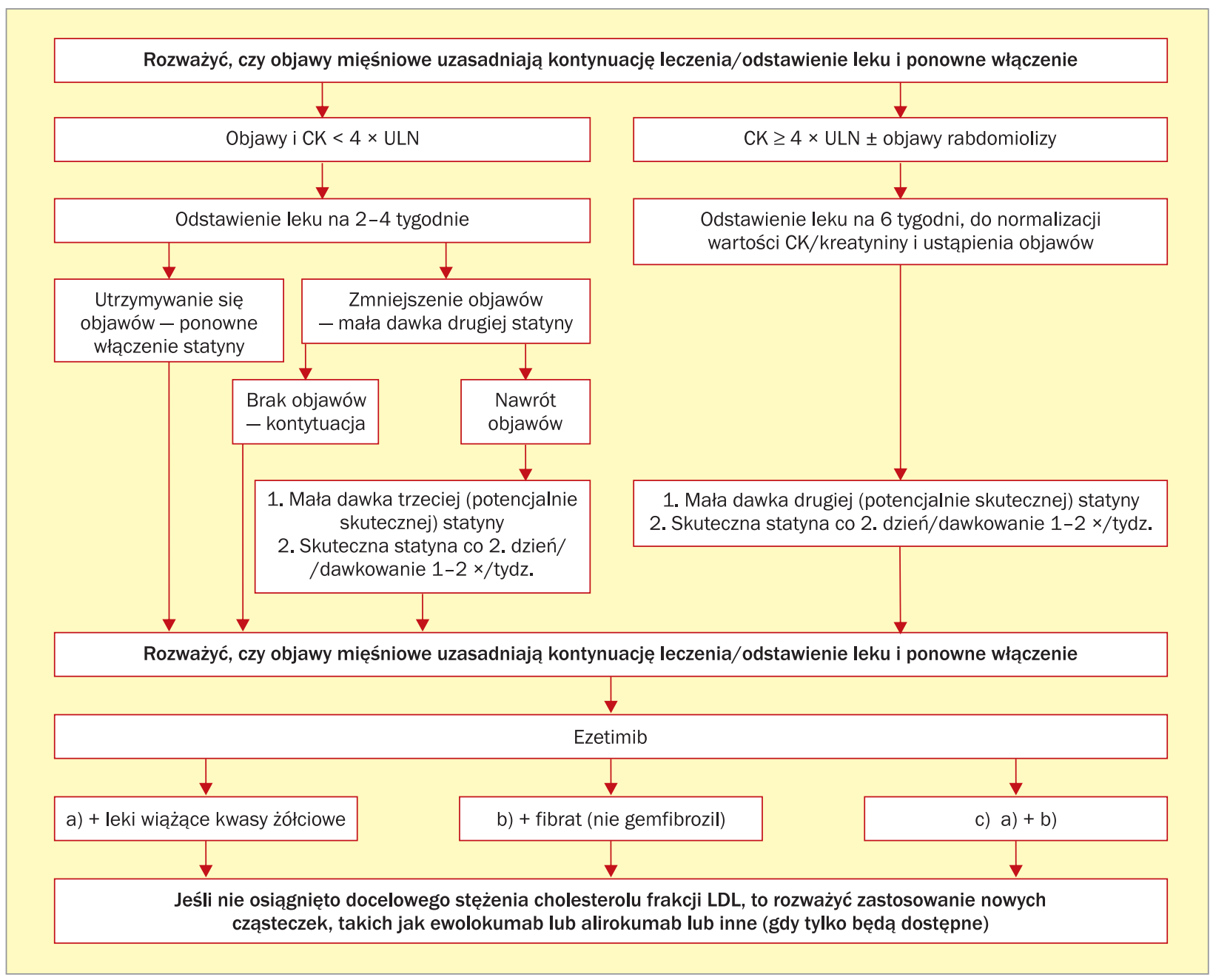

Rycina 1. Algorytm postępowania w przypadku wystąpienia objawów mięśniowych podczas leczenia statyną; CK (creatine kinase) - kinaza kreatyny; ULN (upper limit of normal) - górna granica normy; LDL - low-density lipoprotein 
rydów między lipoproteinami osocza. Inhibitory białkowych transferaz estrów cholesterolu (inhibitory CETP) mogą istotnie zwiększać stężenie cząsteczek cholesterolu frakcji HDL (high-density lipoprotein), a dwie intensywnie obecnie badane cząsteczki - anacetrapib i ewacetrapib - obniżają wartość cholesterolu frakcji LDL o 25-40\%. Podczas stosowania tych cząsteczek w badaniach klinicznych nie wystąpiły żadne działania niepożądane związane z funkcjonowaniem układu mięśniowo-szkieletowego. Podjęto dwa kolejne badania w celu określenia wpływu leczenia inhibitorami CETP na częstość występowania zdarzeń sercowo-naczyniowych (ryc. 1).

\section{Podsumowanie}

Statyny, powodując obniżenie stężenia cholesterolu frakcji LDL, redukują ryzyko sercowo-naczyniowe o ponad $40 \%$ w wielu grupach pacjentów. Głównym powodem zaprzestania stosowania statyn są objawy SAMS. Strategia optymalnego postępowania powinna obejmować zastosowanie najlepiej tolerowanej przez pacjenta statyny, dawkowanej nawet rzadziej niż raz dziennie, lub wdrożenie leczenia skojarzonego z innym lekiem istotnie wpływającym na obniżenie wartości cholesterolu frakcji LDL i o udowodnionym wpływie na ograniczenie występowania zdarzeń sercowo-naczyniowych. Właściwe diagnozowanie objawów mięśniowych związanych i niezwiązanych ze stosowaniem statyn w przebiegu terapii tymi lekami oraz wdrożenie adekwatnego postępowania pozwala uzyskać korzyści wynikające z obniżenia stężenia cholesterolu, przy uniknięciu działań niepożądanych, i zmniejszenie ryzyka sercowo-naczyniowego.

\section{Konflikt interesów}

Autorki deklarują brak konfliktu interesów.

\section{Abstract}

Statin therapy is a fundamental treatment for hypercholesterolaemia. Statin-associated muscle symptoms (SAMS) are one of the main reasons for treatment discontinuation and failure to reduce the risk for cardiovascular events. Strategy for optimal management of patients with SAMS should include the use of a statin that is best tolerated by the patient, dosing the drug even more rarely than once daily, or introducing a combination therapy with other drug known to significantly decrease LDL cholesterol and have a proven effect on cardiovascular risk reduction. Proper diagnosis of muscle symptoms, associated or not associated with statin therapy, and introducing adequate management allows achieving benefits resulting from decreased cholesterol level avoiding adverse effects and, subsequently, provides cardiovascular risk reduction.

Key words: statins, hypercholesterolaemia, muscular symptoms

(Folia Cardiologica 2015; 10, 5: 354-360)

\section{Piśmiennictwo}

1. Filipiak K.J., Cybulska B., Dudek D. i wsp. Aktualne problemy terapii dyslipidemii w Polsce - Deklaracja Sopocka. Stanowisko ekspertów wsparte przez Sekcję Farmakoterapii Sercowo-Naczyniowej Polskiego Towarzystwa Kardiologicznego. Choroby Ser. Nacz. 2011; 1: $1-4$.

2. Stroes E., Thompson P.D., Corsini A. i wsp. Statin-associated muscle symptoms: impact on statin therapy - European Atherosclerosis Society Consensus Panel Statement on Assessment, Etiology and Management. Eur. Heart J. 2015; 36: 1012-1022.

3. Banach M., Rizzo M., Toth P.P. i wsp. Statin intolerance - an attempt at a unified definition. Position paper from an International Lipid Expert Panel. Arch. Med. Sci. 2015; 11: 1-23.

4. Carter A.A., Gomes T., Camacho X. i wsp. Risk of incident diabetes among patients treated with statins: population based study. Br. Med. J. 2013; 346: f2610.

5. Chowdhury R., Khan H., Heydon E. i wsp. Adherence with statin therapy in elderly patients with and without acute coronary symptoms. JAMA 2002; 288: 462-467.

6. Parker B.A., Capizzi J.A., Grimaldi A.S. i wsp. Effect of statins on skeletal muscle function. Circulation 2013; 127: 96-103.
7. Zhang H., Plutzky J., Skentzos S. i wsp. Discontinuation of statins in routine care settings: a cohort study. Ann. Inter. Med. 2013; 158: 526-534.

8. Cannon C.P.; IMPROVE-IT Investigators. IMProved Reduction of Outcomes: Vytorin Efficacy International Trial. A multicenter, double-blind, randomized study to establish the clinical benefit in high-risk subjects presenting with acute coronary syndrome. Dostępne na: http://my.americanheart.org/idc/groups/ahamah-public/@wcm/@sop/@scon/documents/downloadable/ucm_469669.pdf. Data dostępu: 22.11.2014.

9. Stein E.A., Ballantyne C.M., Windler E. i wsp. Efficacy and tolerability of Fluvastatin XL $80 \mathrm{mg}$ alone, ezetimibe alone and combination of Fluvastatin XL 80mg with ezetimibe in patients with a history of muscle-related side effects with other statins: a randomized, double-blind, double-dummy trial. Am. J. Cardiol. 2008; 101: 490-496.

10. Ginsberg H.N., Elam M.B., Lovato L.C. i wsp.; ACCORD Study Group. Effects of combination lipid therapy in type 2 diabetes mellitus. N. Engl. J. Med. 2010; 362: 1563-1574.

11. HPS2-THRIVE Collaborative Group. HPS-THRIVE randomized placebo controlled trial in 25673 high-risk patients of ER niacin/laropiprant: trial design, prespecified muscle and liver outcomes, and reason for stopping study treatment. Eur. Heart J. 2013; 34: 1279-1291. 